\title{
COERCION AND CONCILIATION AT THE EDGE OF EMPIRE: STATE-BUILDING AND \\ ITS LIMITS IN WAZIRISTAN, 1849-1914*
}

\author{
MARK CONDOS and GAVIN RAND \\ QUEEN MARY, UNIVERSITY OF LONDON and UNIVERSITY OF GREENWICH
}

\begin{abstract}
ABTRACT. Since 2001, the geo-strategic priorities of the 'War on Terror' have again drawn global attention to the historically significant region of Waziristan. Now widely regarded as a hotbed of terrorism, violence and anti-statism, Waziristan's colonial history has been mined for 'useful' lessons which might be applied to this contemporary conflict and its ongoing obsession with 'securing' and 'pacifying' dangerous sections of the globe. The instrumentalist bent of much of this work is problematic because it often reproduces the same reductive stereotypes and metrics of imperial success that appear in the colonial archives. This paper offers an alternate frame for writing the history of the colonial frontier through a re-examination of how British officials attempted to construct and impose their authority upon one of the region's most powerful and politically important groups: the Mahsud Wazirs. By identifying a number of crucial, yet largely overlooked, continuities that characterized British efforts to 'pacify' the Mahsuds, this paper provides new insight into the quotidian ways in which an expanding colonial state attempted to constitute itself, as well as a more nuanced picture of how imperial power in this region was historically resisted and shaped by those it sought to control and subjugate.
\end{abstract}

\section{I}

Since 2001, the geo-strategic priorities of the 'War on Terror' have again drawn global attention to the historically significant region of Waziristan, a key and contested imperial periphery throughout the nineteenth and twentieth centuries. ${ }^{1}$ Now widely regarded as a wellspring of terrorism, violence and anti-statism Waziristan's colonial history has, ironically, been mined for 'lessons' which might bear on contemporary efforts to 'secure' and 'pacify' dangerous spaces in the global south. ${ }^{2}$ The instrumentalist bent of much recent writing on Waziristan, and the frontier region more broadly, is problematic - not least because reading colonial policies in terms of their 'success' and 'failure' normalises and dehistoricizes the imperial metrics of pacification upon which such judgements rest. If we want to better understand how British colonial power operated and avoid projecting colonial fallacies onto the present, we need alternate frames for writing the history of the frontier and different ways of thinking about the lessons of the imperial past. A more 
At the edge of empire

critical reading is both possible and necessary. This paper sketches one possible approach by examining the practices and logics that shaped (and limited) British administration of the Waziristan frontier, focusing, in particular, on colonial engagements with the Mahsud Wazirs during the latter half of the nineteenth century. As one of the most powerful and politically important 'tribes' in the region, the Mahsuds's interactions with the colonial state offer useful insights into the means through which imperial authority was constructed and contested. ${ }^{3}$

Although the colonial archive provides rich and detailed accounts of the imperial past, few of the policy-makers and commentators seeking solutions for the present have questioned the perspectives, assumptions, and prejudices of these sources. ${ }^{4}$ These have also been processed into the historiography, much of which has focused on the activities of pioneering officers or on the machinations of diplomats, reproducing the tropes of religiosity, 'fanaticism' and otherness which structure the colonial archive. ${ }^{5}$ These readings proffer essentialized accounts of so-called 'tribal' populations and neatly periodized readings of frontier policies overdetermined by shifting imperial priorities. Christian Tripodi, for example, identifies four phases of colonial frontier policy in India. 'Each phase', he suggests, 'comprised a policy response to the prevailing grand strategic preoccupations of the time'. ${ }^{6}$ Under 'forward' policies, the colonial administration favoured the projection of military power and the use of punitive expeditions to secure tribal obedience; at other times, negotiation, persuasion, or 'masterly inactivity' were favoured. Even more nuanced readings of colonial engagements with the frontier reproduce this high-political schema. ${ }^{7}$

This paper rejects the emphasis on rupture and discontinuity. Instead, it identifies clear and consistent patterns in colonial frontier administration, as well as in the ability of the region's predominantly Pashtun inhabitants to respond to colonial interventions. ${ }^{8}$ Regardless of the prevailing 'grand strategy', colonial engagements on the frontier involved recurrent, if ostensibly 
At the edge of empire

inconsistent, attempts to forcibly re-order social and political relationships with the Mahsuds. While violence was central to these projects, the imperial military was much more than a coercive force periodically called forth to exact revenge where the peace had been disturbed. Instead, the military was engaged in a range of material and epistemological endeavours which often supported more 'conciliatory' modes of intervention. These included attempts to engineer Mahsud loyalty through economic and political patronage, via land colonization schemes, paramilitary employment and the provision of tribal allowances. Tracing these strategies (and their limits) across the late nineteenth century not only provides us with important insight into the quotidian ways in which the expanding colonial state sought to constitute itself, but also offers a more nuanced picture of how colonial power responded to and was shaped by the actions of those it sought to control and subjugate.

Though we seek to emphasise the ability of the frontier population to deflect and divert colonial expansion, we do not intend to suggest that the 'recalcitrant' nature of frontier society is principally an 'effect' of imperial expansion (be it British, Sikh, Mughal or otherwise). If tribal social organisation comprised a form of 'institutionalised dissidence', as Akbar S. Ahmed has suggested, it is equally revealing to examine colonial projects of rule as attempts to institutionalise new forms of obligation and quiescence. Assuming that '[e]thnicity and tribe begin where taxes and sovereignty end', we need to better understand how this complementarity was produced. ${ }^{9}$ Thus, in distinction to James C. Scott's suggestive mapping of 'Zomia' as a place of refuge from, and resistance to, expanding state power, this paper traces the contours of more reciprocal exchanges between the settled districts of colonial Punjab and the hinterlands of the frontier. It argues that in Waziristan, the frontier encounter was a dialogic, symbiotic one in which both coercive and conciliatory modes reflected the material and epistemological foundations of the 
At the edge of empire

colonial project of rule. Viewed from this perspective, colonial officers were at least as 'fanatical' in their adherence to these modes of thinking and governing as their local antagonists were in their engagements and resistance. Examining these parallels and limits offers an alternative to the simplistic and reductive pillaging of the imperial past for 'useful' lessons on the management of the imperial present.

<PLEASE INSERT FIGURE 1: MAP OF THE NORTH-WEST FRONTIER c. 1901〉

\section{II}

Although the northwest frontier has often been regarded as distinctive, the measures developed to administer the region were similar to schemes devised to pacify (or 'civilise') a host of different populations in colonial South Asia. Groups who did not conform to the ideal of the sedentarized, revenue-paying cultivator were stigmatized and depicted as 'predatory' and threatening to the interests and security of the colonial order. ${ }^{10}$ According to this logic, 'predatory', 'tribal', and 'criminal' peoples forfeited their rights to the protections normally afforded by law, requiring instead to be pacified and policed through extraordinary - often violent - methods. ${ }^{11}$ Alongside legal and extra-legal violence, however, one of the principal mechanisms by which colonial administrators sought to create productive and quiescent subjects was through the creation of a land-owning class whose interests were coterminous with those of the British. ${ }^{12}$ Colonial officials envisioned the creation of peaceful, industrious, 'civilized', revenue-paying cultivators, whose loyalty would be ensured by their gratitude to the British as well as by a newfound prosperity from their legitimate agrarian pursuits.

As Robert Nichols and others have shown, similar strategies were employed on the northwest frontier, where irrigation and land grants, in concert with military employment and 
At the edge of empire

pensions, were deployed as means of tying Pashtun interests to the state. ${ }^{13}$ In the early 1850 s, for example, newly-irrigated land was granted to Pashtun tribesmen who had fought alongside the British in the Second Anglo-Sikh War (1848-49). According to Reynell Taylor, the Deputy Commissioner of Dera Ismail Khan:

the effect of all is in a great measure to provide employment and subsistence for a number of deserving men, some of whom have fought for us in the field, and further, to colonise a tract of country hitherto only inhabited by unruly half-reclaimed Afghan classes, who have been but a few years subject to any Government at all, with a strong body of loyal and civilized men belonging to provinces long under strict subjection, and therefore likely to side with order and discipline against sedition, treachery, hill influence, $\&$ c. ${ }^{14}$

As Taylor makes clear, these projects literally inscribed the colonial presence in the landscape, providing a material foundation for the reworking of relationships between the colonial state and its emerging subjects. Such colonization schemes, which typically went hand-in-hand with military and paramilitary recruitment, were initiated (to varying degrees of success) with nearly all of the frontier's major Pashtun groups, including the Afridis, Wazirs, Gurchanis, Bhittanis, and Bugtis. ${ }^{15}$

By 1865 , the only major frontier tribe without any settlements or lands in British territory were the Mahsuds of South Waziristan. Throughout the colonial period, the Mahsuds were regarded as amongst the most truculent and intractable tribes: in 1932, C.C. Davies reported that though 'every endeavour was made to cultivate friendly relations... the tribesmen continued to murder our subjects and to harass our borders'. ${ }^{16}$ Davies lamented that 'practically every conciliatory method and every form of coercion have been attempted, but, after the lapse of more than three-quarters of a century, no real solution has been discovered'.${ }^{17}$ Davies presents colonial 
At the edge of empire

policy torn between two apparently conflicting impulses: conciliatory attempts to civilize and coercive actions to compel submission. The distinction posited between 'conciliation' and 'force', however, obscures the fact that 'punitive' expeditions often worked in tandem with settlement programmes and other schemes for 'pacification' (including the payment of tribal allowances and paramilitary recruitment).

Typically mounted in retribution for 'crimes' committed within 'British territory', punitive expeditions were described in quasi-judicial terms. R.H. Davies, the Secretary to the Government of Punjab, wrote in 1865 that: 'the despatch of an expedition into the hills is always in the nature of a judicial act. It is the delivery of a sentence, and the infliction of a punishment for international offences'. ${ }^{18}$ To inflict such punishment, colonial forces crossed the border and entered tribal territory to strike 'rapid blows at vulnerable points' before retreating. Eventually, these so-called 'butcher and bolt' campaigns gave way to larger operations which called for more protracted occupation of tribal territory in order to 'thoroughly master the enemies' country and dictate terms at leisure in their midst' ${ }^{19}$ By the turn of the twentieth century, doctrinal instruction on conducting such 'small wars' was widely circulated and frontier campaigning elicited considerable popular interest and a good deal of salacious reportage, some of which has reproduced in the historiography. ${ }^{20}$ The reality of frontier warfare, however, was typically less romantic than popular writings suggested. Because tribal populations usually retreated in the face of advancing colonial forces, frontier campaigns offered few opportunities for sustained military engagements. As a result, 'mastering the enemy's territory' demanded a spatial and material performance, in which colonial troops undertook symbolic route marches through tribal territory, seizing grain and fodder, and destroying forts, villages, and other tribal infrastructure. ${ }^{21}$ Mapping and surveying provided further opportunities to 'master' tribal territory and extend colonial dominion. Like 
At the edge of empire

settlement schemes, military expeditions invariably revolved around attempts to physically reorder the economic and material conditions in which the frontier's inhabitants lived.

Although recent scholarship on India's northwest frontier provides a useful starting point for thinking about how authority was constituted along the imperial periphery, the general thrust of this work has tended to exaggerate the 'exceptional' nature of this encounter. ${ }^{22}$ While colonial authorities undoubtedly conceived of the frontier and its inhabitants as distinct from the rest of India, they also tenaciously clung to the belief that the 'frontier tribes' might someday be fashioned into conventionally productive colonial subjects. 'Frontier governmentality' was thus more similar to David Scott's notion of 'colonial governmentality' than is often acknowledged. ${ }^{23}$ Moreover, with its prevailing focus on the state's legal and administrative apparatus, much recent work has overlooked the crucial ways that 'frontier governmentality' was equally, and in some ways more importantly, assembled through material interventions.

As we shall see, economic conciliation and military coercion were complementary components of a wider strategy that sought to establish new relations of force to facilitate the domination of frontier populations in novel and pervasive ways. Ostensibly 'conciliatory' methods attempted to discipline tribal populations by inculcating new forms of sedentary or bonded labour, often aided by military and paramilitary recruitment. Punitive expeditions worked to erode the ability of tribal groups to resist and evade colonial authority by both destroying their material capacity to sustain themselves independently, and by rendering their territory more legible and thus more vulnerable to future incursions by the state. Thus, rather than being discrete spheres or tools of colonial governance, these methods actually bled into one another. On the northwest frontier, colonial governmentality inhered in forms of knowledge, property, and labour just as much as in law, and in the physical acts of destruction perpetrated by the military. The violence of 
At the edge of empire

the colonial frontier was therefore at once more dispersed, and at the same time more proscribed, than is typically understood. To chart the history of this violence more clearly, the following section turns to Waziristan and to colonial relations with the Mahsuds.

\section{III}

Following the annexation of Punjab in 1849, the Mahsuds swiftly emerged as a disruptive and dangerous presence on the colonial frontier. ${ }^{24}$ The tribe was held responsible for a variety of infractions, including 'raids' against villages in British territory and attacks on the Powindah caravans that plied annual trade routes through the Gomal valley. ${ }^{25}$ Matters were brought to a head in 1860, when 3,000 Mahsuds, led by Janji Khan, a prominent malik (chief), attacked the town of Tank. Though the raiders were turned back and Janji Khan was killed, the boldness of the attack was taken as evidence that colonial influence on the frontier was under-developed. ${ }^{26}$ As a result, an expeditionary force - comprising more than 5,000 troops and 1,600 irregulars under the command of Major General Sir Neville Chamberlain - was dispatched against the Mahsuds in March 1860 to 'exact satisfaction for the past and security for the future'. ${ }^{27}$

Contrary to colonial expectations, the Mahsuds made no attempt to resist the initial advance of colonial troops. ${ }^{28}$ In fact, apart from a single incident in which a reconnaissance party was engaged by a small number of tribesmen, colonial forces found few opportunities to close with the Mahsuds. In the absence of tribal submission and in lieu of opportunities for a direct confrontation, Chamberlain sent troops to destroy fortifications and habitations associated with the late Jangi Khan. To underline the punitive purpose of the operations, property belonging to another Mahsud malik not involved in the raid on Tank was spared 'purposely to mark the distinction between the conduct of the two men'. ${ }^{29}$ While the expedition's advance parties proceeded unopposed, the 
At the edge of empire

Mahsuds launched a large counter-attack on the reserve camp on 23 April, prompting the expansion of colonial operations to punish the tribe as a whole. On 5 May, colonial forces set out for the more distant settlement of Kaniguram, which was believed to be the principal town in South Waziristan. Kaniguram was occupied until 9 May, and was spared only after the town's inhabitants offered to pay a fine. As no submission had been received from the Mahsuds, the colonial force withdrew, 'setting fire to everything which had been protected on its upward march'. ${ }^{30}$ Indicatively, when troops moved beyond Mahsud territory, fodder and provisions were paid for, signaling the punitive calculus which underpinned their earlier plundering.

Although colonial troops destroyed a significant amount of Mahsud property and killed a number of tribesmen, the expedition withdrew without securing the tribe's official submission. Rather glossing over this fact, the official history recorded that the expedition was a great success. If the occupation of Kanigorum was intended to demonstrate the ability of colonial troops to strike deep into Mahsud territory, it was the destruction of tribal property and foodstuffs which constituted the truly 'punitive' effects of the expedition. Chamberlain emphasized the necessity of the material assault against tribal property:

If objection be taken to the nature of the punishment inflicted as repugnant to civilization, the answer is that, savages cannot be met and checked by the rule of civilized warfare; and that to spare their houses and crops would be to leave them unpunished, and therefore unrestrained. $^{31}$

The trope of 'savagery' which inflects Chamberlain's pre-empted criticism of the methods adopted and disguised the inability of colonial troops to engage, much less to defeat, the Mahsuds. In this 
At the edge of empire

sense, the methods adopted during the 1860 expedition suggest the limits of imperial military power as much as they reflect the unique demands of 'savage warfare'. Undaunted, Chamberlain declared himself to be 'sanguine' about the effects of the operations, concluding that 'sooner or later the result of the expedition will be to bring about a state of peace hitherto unknown on this blood stained border' ${ }^{32}$ In fact, the expedition did little to bring about the radical shift in the tribe's disposition and the Mahsuds came to terms in 1861 only after a protracted and costly blockade (bandish).

Given the impossibility of obtaining a decisive military victory and the impracticality of maintaining an indefinite blockade of their territory, frontier officials began to envision alternative ways of pacifying the Mahsuds. In December of 1861, Taylor remarked that British policy towards the Mahsuds had hitherto failed to address and reform the underlying causes of the tribe's misconduct. 'We have to change the hereditary habits of the most unruly subdivisions of a proverbially unruly tribe', he wrote, proposing that the best method of doing so would be to 'locate a portion of these plundering subdivisions' on agricultural lands, in order to substitute agriculture for their 'natural employment'. ${ }^{33}$ Taylor hoped that the establishment of 'Mahsud colonies' would both inculcate 'agricultural habits' and reduce raiding. In 1865, S.F. Graham, the Deputy Commissioner of Dera Ismail Khan, similarly argued that 'the only way to reform this tribe and to give peace and prosperity to this part of the border is... to offer to the Mahsoods... a more legitimate field for the display of their energy and spirit by giving some of them service on their border and lands on which others may locate in our territory." 34

Although skeptical of the scheme, Viceroy John Lawrence agreed that Graham's proposal 'should have a fair trial on account of its great importance'. ${ }^{35}$ To this end, he approved a budget of Rs. 5,000 to facilitate the settlement of Mahsud 'colonists', provide agricultural implements, 
At the edge of empire

and to purchase cattle as well as shelter and food until cultivation had been sufficiently established that they could begin supporting themselves. ${ }^{36}$ The scheme specified that the Mahsuds be granted rent-free land for ten years in the area surrounding Tank, as well as employment in the frontier militia. Wasteland was selected from tracts between the Sheorani Hills and the cultivated Gomal Valley, both to avoid upsetting existing proprietary claims and because of the area's favourable potential for irrigation. Secretary of State for India George Robinson gave his personal blessing to the project, asserting that 'The pacification of border tribes by humanising influences is more likely to be permanent than their subjection by military force'.${ }^{37}$ Colonial optimism, however, proved to be premature and the project was abandoned in 1866 due to deteriorating relations with the Mahsuds, ostensibly caused by disputes over the distribution of land and militia positions to the various subdivisions within the tribe. ${ }^{38}$ The failure of the stillborn settlement scheme seemed to vindicate those critics who doubted the viability of such 'humanising influences'. According to one report from December of 1866, 'It is evident... that it is the excitement, honour, and impunity of a life of plunder, and not the want of other means of livelihood, that cause the incessant misbehaviour of these mountain tribes'.39

Despite the failure of the first settlement scheme, and the persistence of essentialist readings of Pashtun society, interest in establishing a Mahsud colony was revived in January of 1877 after malik Gholam Nabbi Khan formally petitioned the Punjab Government for grants of wasteland in the Tank Valley. In return, Nabbi Khan promised to establish villages on these lands and to encourage members of his clan to settle and 'reside there as British subjects'. ${ }^{40}$ The new scheme was embraced by both the Punjab Government and the Government of India (GOI). Deputy Commissioner of Dera Ismail Khan C.E. Macaulay gave his full backing to Nabbi Khan's proposal, asserting it would produce 'great political advantage' by strengthening British influence 
At the edge of empire

and encouraging the Mahsuds to accept responsibility for guarding the Gomal Pass. ${ }^{41}$ 'Once the Mahsuds acquire the habit of leaving the hills and cultivating land in British territory', he wrote, 'I think in the course of a few years the habits of the whole tribe would undergo considerable change, and our power of control over them would be strengthened in a very decided degree' ${ }^{42}$ Lieutenant-Governor Robert Davies was equally optimistic, reporting to the Government of India that the Mahsuds were finally prepared to abandon their predatory ways and enter into a new era of peaceful cooperation. ${ }^{43}$ To facilitate this transition, the GOI sanctioned the purchase of 3,618 acres of land, and two hundred 'leading' families of the three main branches of the Mahsuds - the Alizais, Shaman Khels, and Bahlolzais - were settled in British territory. ${ }^{44}$ The revival of the scheme reflected the persistent assumption that settling the Mahsuds would produce a radical change in their behaviour, making the tribesmen into quiescent and productive colonial subjects. For a time, it appeared that some progress was being made; in 1878, one official claimed that 'the plains of Tank, never formerly at rest from Mahsud outrages, enjoyed an unexampled security of life and property'. ${ }^{45}$

This unprecedented peace, however, was 'rudely broken' on 1 January 1879 when between 2,000 and 3,000 tribesmen attacked the town of Tank, sacking the bazaar and looting significant amounts of property. This 'gross and open violation of British territory' was instigated by Umar Khan, son of the late Janji Khan. Umar Khan appears to have been motivated by a combination of his desire to avenge the death of his father, resentment at having been side-stepped as the main channel of communication between Macaulay and the Mahsuds in favour of Nabbi Khan, and his loyalty to the Afghan Amir, Sher Ali Khan. ${ }^{46}$ Seizing upon the widespread disaffection that permeated the frontier in the wake of the recent British invasion of Afghanistan at the commencement of the Second Anglo-Afghan War (1878-1880), Umar Khan heeded Sher Ali 
At the edge of empire

Khan's exhortations to wage jihad against the British and rallied his supporters to attack Tank. ${ }^{47}$ This incident reveals not only the complex and entangled political loyalties at stake on the frontier, but also demonstrates the considerable influence that a single, disgruntled Mahsud leader could have in upsetting the delicate alliance the British were attempting to forge with other members of the tribe. The assault on Tank confounded the optimistic assessments which had accompanied the resurrected settlement scheme and sparked a series of uprisings along the frontier. ${ }^{48}$ The pacification of the Mahsuds - and of the Waziristan frontier more generally - seemed as distant in 1879 as it had following the first attack on Tank in 1860.

\section{IV}

With the Indian Army occupied by the Second Anglo-Afghan War, the colonial authorities had limited means to seek redress for the 1879 raid. A blockade was re-established to prevent the Mahsuds from entering or trading with British territory, though its effectiveness was constrained by the fact that the tribe remained less dependent than other Pashtun groups on trade with British India. ${ }^{49}$ It was not until 1881, after the cessation of hostilities in Afghanistan, that a punitive expedition was finally sent to 'settle' the affair.

The stated objectives of the 1881 expedition were to recover property plundered in the 1879 raid, extract payment of a Rs. 30,000 fine, and compel the surrender of the six headmen who were believed to be the ringleaders of the attack. Typically, the expedition was meant to project colonial power and authority by demonstrating the capacity of British troops to penetrate Mahsud territory and bring the tribe to heel by disrupting their means of subsistence. ${ }^{50}$ Far from being barren fastnesses, as was often suggested, the commander of the Punjab Frontier Force, T.R.G. Kennedy, noted that Mahsud territory was home to 'elaborate' and 'ingenious' irrigation systems. 
At the edge of empire

In preparing his plans for the expedition, Kennedy requested a detachment of 300 Mazhabi Sikh pioneers to dismantle the irrigation works, arguing that their destruction 'would cause great loss'. ${ }^{1}$ Further, he proposed to threaten annual expeditions timed to destroy the crops upon which the tribe relied. ${ }^{52}$ Though rather fantastical, the proposal indicates that the logic of frontier warfare was calculated not in conventional military terms, but as a means of imposing a regularized, temporal discipline upon the tribes. While the colonization schemes of the preceding decades had sought to control the tribesmen by settling them as pastoralists and agriculturalists, the punitive expeditions aimed to discipline the Mahsuds by undermining their ability to sustain these practices independently.

Although Kennedy's proposal for annual expeditions was rejected, the Punjab Government insisted that the 1881 expedition should demonstrate the capacity of colonial troops to penetrate and disrupt Mahsud territory. The Punjab Government instructed the commanding officer that 'the force should traverse and explore as much of the Mahsud hills as possible, and... your operations should be deliberate and free from all appearance of haste'. ${ }^{53}$ While the performative logic here is clear enough, these operations also offered opportunities to seize tribal crops and property and to consolidate colonial knowledge. Some 300 square miles of the frontier were mapped, and a number of nearby peaks triangulated. According to one report, 'Much new country has been unveiled and valuable survey operations have been secured'. ${ }^{54}$ Here, as in previous operations, strategic and economic imperatives were complementary. The penetration and exploration of tribal territory involved requisitioning food and supplies, straining the Mahsud economy, while the collection of cartographic and ecological information rendered the tribe more susceptible to future economic disruptions effected by the colonial state. ${ }^{55}$ Frontier warfare, as Akbar S. Ahmed points out, was 'invariably linked with the pattern of crops and cultivation', and the colonial state readily 
At the edge of empire

appropriated and exploited this connection. ${ }^{56}$

The 1881 operations also reflect the fact that, as in 1860 , the Mahsuds chose to harry and harass rather than confront the expeditionary forces. According to the official report, neither of the force's two columns were seriously engaged during the operations. In the absence of decisive military encounters, cartographic conquests provided a convenient and quantifiable proxy to demonstrate the expedition's 'success'. However, for all the optimism conveyed in military accounts of the 1881 operations, there is little to suggest that the expedition was a success. When colonial troops were withdrawn a month after operations began, none of the principal objectives had been secured: the tribe had not submitted, no fines had been paid, and the ringleaders and stolen property from the 1879 raid remained at large. Indeed, it was only four months after the conclusion of the expedition that the Mahsuds came to terms. In return for the lifting of the blockade, several of the individuals wanted for the raid on Tank were delivered into colonial custody, and a further 80 hostages were made over in the hope of improving security on the frontier. ${ }^{57}$ By this point, the fines incurred by the tribe had reached such a level that the outstanding amount was converted into a tax on Mahsud goods traded in India. ${ }^{58}$ This conversion suggests, once again, the confluence of military and economic engagements along the frontier. It is hardly surprising, then, that one of the staples of frontier intelligence - and one of the measures used to evaluate the effectiveness of intervention - was the price of grain. ${ }^{59}$ Grain was not only one of the 'sinews' of guerilla warfare, as Richard Temple claimed in $1856,{ }^{60}$ but was also one of the mechanisms through which a new form of colonial order was negotiated on the frontier. Indeed, following the conclusion of operations in 1881, the Pioneer speculated that the Mahsud maliks eventually submitted because further hostilities might disrupt that year's 'extraordinarily fine crops'. ${ }^{61}$ 
At the edge of empire

The 1881 expedition, like the abortive settlement scheme it succeeded, sought to establish novel forms of control along the frontier by reorganizing material relations between the colonial state and the tribe. This was not simply 'butcher and bolt': the occupations and negotiations were protracted, and reflected the ideological, technological, and epistemological apparatus on which frontier campaigning depended. Thus configured, military interventions bore much in common with the less familiar settlement and colonization schemes, particularly in their attempt to establish more pervasive and permanent forms of control. Whether through the destruction of the Mahsuds's material capacity to resist, the mapping of tribal territory, or the attempt to impose more regularized forms of extractive taxation, punitive expeditions - like the settlement schemes represented attempts by the colonial state to engineer new forms of governance along the frontier.

Following the 'submission' of 1881 a period of relative stability prevailed on the South Waziristan frontier. Trade through the Gomal Pass was reopened, and the Mahsuds agreed to provide an escort for a survey party's visit to the pass in 1883. Optimistically, colonial officials attributed this change to the effects of the late expedition, and some began to press again for the resurrection of the colonization schemes. In April 1882, E.L. Ommanney, the Commissioner of Derajat, claimed that the 'complete submission' obtained from the Mahsuds in the wake of the 1881 expedition was proof that the tribe was finally ready to reform its unruly ways by taking up residence in British territory as settled agriculturalists. ${ }^{62}$ With support from both the Punjab Government and the Government of India, officials set about dividing the land previously purchased for the 1877-79 scheme, and 40 Mahsud families were gradually settled in the colony between 1882 and 1887.

Early assessments of the new scheme were positive. In 1884, the Gazetteer of the Bannu District reported that 'the interposition of colonies of Waziris between the more settled portion of 
At the edge of empire

the plains and the hills has, more than any measure, tended to secure the peace of the frontier. Experience has shown too, that these rough mountaineers are capable of being tamed and converted into peaceful agriculturists. ${ }^{63}$ Despite this initial optimism, enthusiasm for the project quickly cooled. In February of 1885, S.S. Thorburn, the Deputy Commissioner of Dera Ismail Khan, reported that many of the Mahsud 'colonists' were merely using the land to 'squat' temporarily during the cold season, and were returning to the hills in the hot weather. Very few, he added, were cultivating the land themselves, relying instead on the use of Jat agricultural labourers. Thorburn's report cast severe doubts on the practicability of the colonization scheme, concluding that too few families were settled on the land to effect a radical change in the behaviour of the entire tribe. ${ }^{64}$ G.M. Ogilvie, the new Deputy Commissioner, came to the same conclusion two years later in 1887 , warning that 'the settlement of a few will not civilize the rest' ${ }^{65}$

Scepticism increased the following year when large numbers of armed men prevented a colonial survey party from mapping the Gomal Pass. As a result, the 'hostages' given in 1881 were dismissed, confirming that the practice of hostage-taking was essentially a means of incentivizing the tribe's good behavior. By 1892, it was clear that the settlement project was running out of steam. In March of that year, Ogilvie's successor, L.W. King, reported that fewer than 30 families were living on the land, cultivating a meagre total of 66 acres. From this, he concluded that the Mahsuds showed 'little or no predilection for agricultural pursuits'. For King, the only way to teach the Mahsuds the true value of possessing these lands was by fostering a sense of private ownership, something which the previous schemes had failed to achieve. As he put it, 'these lands have hitherto been regarded as the joint property of the whole tribe, which acts as a bar to individual interest'. ${ }^{66}$ In light of all this, King came to the view that the initial British goal of permanently settling a large portion of the tribe was unworkable. 
At the edge of empire

Pessimism was reinforced in 1894 when certain Mahsuds frustrated yet another attempt to survey the frontier during the demarcation of the new Indo-Afghan border. While the fixing of the 'Durand Line' is often read as evidence of a more assertive 'forward policy', the attempt to delimit the frontier brings into focus the precarious nature of colonial authority in South Waziristan. Though the survey party was accompanied by a substantial military escort, a tribal force numbering between two and three thousand men mounted a surprise attack at Wana on the night of 2 November 1894, killing 45, wounding 75, and carrying off a substantial haul of rifles and other property. In response, a third punitive expedition was organized against the Mahsuds in December of 1894. The expedition demanded the surrender of the ringleaders of the attack at Wana and the restoration of the stolen property, as well as the expulsion from Mahsud territory of Mulla Powindah, who was acquiring some notoriety as an anti-colonial leader. ${ }^{67}$ The 1894 expedition proceeded in much the same manner as the earlier campaigns, with colonial troops finding few opportunities to directly engage tribal forces. ${ }^{68}$ Operations continued until March of the following year, and were consigned mainly to symbolic attacks on the villages and property of those sections thought to be implicated in the attack at Wana. Colonial forces seized large quantities of grain and animals, and destroyed towers and settlements belonging to hostile sections. ${ }^{69}$

When the last of the wanted men finally surrendered themselves in March, the colonial account with the Mahsuds was deemed 'settled'. ${ }^{70}$ Though there were 'very few' Mahsud casualties during the operations, the expedition was said to have been 'absolutely successful'. 'All sections of the Mahsud tribe concerned in the attack at Wana were severely punished', the report continued, and 'our troops penetrated into the remotest glens of the Mahsud country, and lifted the "purdah" from the enemy's most inaccessible strongholds'. ${ }^{71}$ While the performative logic of these operations is again clear, it is also noteworthy that the 1895 settlement once more sought material, 
At the edge of empire

as well as symbolic, submission from the Mahsuds. The tribe was required to discharge all outstanding fines, then standing at Rs. 12,828. At the same time, the tribe's annual allowances were increased by more than Rs. 10,000. Perhaps unsurprisingly, the Mahsuds 'cheerfully subscribed' to the terms proposed. ${ }^{72}$ Through these payments it was hoped that 'legitimate and influential' maliks could be mobilized to assist in the pacification of the tribe.

Similar motives prompted Commissioner of Derajat Richard Bruce to attempt another revitalize the settlement scheme. In 1896, in accordance with Bruce's plan, the Punjab Government offered the Mahsuds 8,600 acres of new land located along the Kot Azam inundation canal. ${ }^{73}$ As a further incentive, the government sanctioned the construction of hamlets for any would-be settlers. ${ }^{74}$ To address the problems identified in previous schemes, new conditions were introduced to increase the grantees's ties to the land. Grants were made unalienable by either sale or mortgage, and had to be worked exclusively by Mahsud tenants, whose good conduct was the responsibility of their respective maliks. Maliks also had to ensure they provided tenants to at least half their lands within a period of 12 months, and that all their lands were occupied within 18 months. ${ }^{75}$ These new terms were intended by Bruce to promote the sense of private ownership and individual interest that King and others had argued were lacking in previous colonization schemes.

While the architects and proponents of successive colonization schemes were eager to emphasize their innovations, the novelty of their schemes seems often to have been exaggerated, presumably as a means of self-promotion; the tactics may have varied across time, but the broad strategy and mechanisms remained the same. The so-called 'maliki' system championed by Bruce, for instance, operated in much the same way as the earlier attempts to reorient the material and political bases of Mahsud society into structures that were intelligible for and amenable to British governance. In relying on the Mahsud maliks to use their influence and ability to persuade or co- 
At the edge of empire

opt their fellow tribesmen, it also drew on methods pioneered by Robert Sandeman in Baluchistan. Whether as attempts to induce wide sections of the Mahsuds to settle in British territory, or to create an influential group of maliks with propertied interests, British strategy sought to re-order the social, political, legal, and economic relations between the tribe and the colonial state.

The apparent inconsistencies of frontier policy - shifting from coercion to conciliation, forward to close border - thus disguise broader continuities across the period in question. The evolving relationship between the Mahsuds and the colonial state was shaped less by the dictates of metropolitan strategy than by recurring engagements which reflected the modes of governance on which colonialism in India developed. Both coercive and conciliatory modes worked to restructure economic and material relations between the Mahsuds and the colonial state. Expeditions, like the settlement schemes, sought to impose new forms of discipline calculated to effect novel relations of domination and subordination. While these relations could be mobilized through the disruption of tribal pastoralism or the irrigation and subsidy of colonial agriculture, the wider objectives of colonial rule are more clearly signified by the recurrent, and determined attempts to penetrate, survey and subordinate tribal populations and territory. It is important to emphasize that the broad similarities between these methods do not reflect a singular or coherent strategy devised by frontier officers. Rather, they are better understood as reflections of the colonial state's fundamental orientation toward refashioning Indian society by asserting political, legal, and material control over property relations more generally. ${ }^{76}$ At the same time, the ready resistance that confronted these schemes suggests a calculating and reflexive opposition on the part of the tribes. It was the dialogic interaction of these forces which shaped the unfolding of colonial history on the frontier. 


\section{V}

On 27 November 1907, less than two years after returning from the Viceroyalty of India, George Nathaniel Curzon delivered the annual Romanes Lecture on the subject of 'Frontiers' to a packed audience at the University of Oxford. Frontiers, Curzon claimed, were 'the razor's edge on which hang suspended the modern issues of war or peace, of life or death to nations'. ${ }^{77}$ 'The Roman Empire', he continued, 'nowhere so near like our own as in its Frontier policy and experience... finally broke up and perished because it could not maintain its Frontiers intact against the barbarians'. To avoid following the Romans into decline, Curzon urged the development of what he called a 'science' of frontier management through which the unruly and 'fanatical' inhabitants of the world's frontiers might be tamed.

Throughout his time as Viceroy (1899-1905), Curzon had devoted considerable energy to overhauling the administration of India's notoriously 'turbulent' and strategically vital northwest frontier. ${ }^{78}$ While his vision of the frontier evoked romanticised notions of chivalry and adventure, Curzon's prescription for a more 'scientific' frontier administration reflected a preference for streamlined imperial governance and, in particular, a desire to reduce military expenditure. ${ }^{79}$ When juxtaposed against the putative 'forward policy' of his immediate predecessors, Curzon's administration appears to mark a significant shift in the nature of colonial frontier policy: while thirteen punitive expeditions were despatched to the northwest frontier in the 1890 s, none were undertaken during Curzon's term as Viceroy. This purported shift has since been reproduced in much of the existing historiography, reinforcing the perception that the colonial administration of the frontier was overdetermined by radically changing strategic priorities. However, while Curzon, like the more junior officials he directed, was at pains to emphasize the novelty of his approach, a more careful reading of the evidence from Waziristan suggests an alternative interpretation. 
At the edge of empire

When Curzon assumed the Viceroyalty in 1899, colonial relations with the Mahsuds were problematic and, despite the various expeditions and colonization schemes, the frontier remained 'unsettled'. Though the Mahsuds had been 'quiet' during the 1897 Uprising, trade through the Gomal Pass remained vulnerable, and over the next several years, Mahsud tribesmen were responsible for a series of thefts, raids, murders, and kidnappings of British subjects. Matters were brought to a head in October of 1900, when a party of Mahsuds attacked a militia post, killing two and capturing ten Snider rifles. By this point, the sum of unpaid fines owed by the tribe had reached a staggering Rs. 1,87,000. As a result, in early November, W.R.H. Merk, the Commissioner of Derajat, convened a tribal jirga at Tank and demanded the Mahsuds settle the outstanding amount. The tribe's request for two months's grace to assemble the money was refused. On 1 December 1900, another blockade against Mahsud territory was implemented. ${ }^{80}$ While payments towards the fine were received by the colonial authorities throughout 1901, further offences continued during this period. It was thus decided that the blockade would be 'amplified' by punitive raids against Mahsud villages. The effects were said to be significant. ${ }^{81}$ In a telegram to H.A. Deane, the Commissioner of the newly-created North-West Frontier Province (NWFP), Merk reported that the combined effect of the blockade and attacks produced more suffering than in any of the previous operations. ${ }^{82}$ In January of 1902 , the tribe's leading men sent in letters of submission.

The 'enhanced blockade' operated in much the same way as the previous expeditions: the punishment of the tribe was effected via the destruction of property and resources. Though these operations often included a performative element, colonial attempts to discipline the Mahsuds continued to operate principally in the material sphere. ${ }^{83}$ Merk clearly recognized that the pacification of the Mahsuds could never be achieved through coercion alone. Allowances and employment in the militia and as labourers on construction and work projects, Merk believed, 
At the edge of empire

would help the Mahsuds to be 'broken into sepoys' ${ }^{84}$ Even the more cautious Deane allowed himself to muse that the late blockade might finally succeed in obtaining the radical transformation that British authorities so desperately desired. ${ }^{85}$ Other frontier officials, however, were less optimistic. Noting that arms trafficking had increased dramatically in the last few years, ${ }^{86} \mathrm{P}$. Pipon speculated that instead of using their tribal allowances and profits from the colony to promote peaceful agricultural interests, many maliks and other tribesmen were using them to purchase weapons. ${ }^{87}$ Attacks on the militia in order to obtain highly-prized Snider rifles were also common. Following one such attack in May 1902, Nazam Khan, a member of the South Waziristan militia, claimed that the man who stole his rifle shouted: 'The Feringis have said that they are going to settle us, there, that's our answer'. ${ }^{88}$ Some colonial officials suspected that the militia colluded with the attackers, and there was widespread anxiety that many recruits enlisted with ulterior motives. ${ }^{89}$

Pipon expressed similar concerns about the Mahsud colony, which he thought had become a haven for criminality. According to him, the tribesmen had not only abused and intimidated those charged with overseeing and assessing the colony's progress, but had used it both as a staging ground for raids into British territory and as a repository for arms and stolen goods. As he saw it: 'there is no doubt the colony had the worst influence on surrounding clans. It was, as a Gundapur Khan dryly described it, a "school of badmashi [criminality] opened by Government for the instruction of our young men", 90 Just as Mahsud 'hostages' used the allowances and access they were granted to British territory in order to arm themselves with superior weapons, the colonists and militia men appropriated the resources provided in order to subvert them for their own ends. ${ }^{91}$ While it is hardly surprising that some officials worried about the 'disintegrating effect' of colonial interventions, their various responses were invariably overdetermined by essentialist readings of 
At the edge of empire

Mahsud society. ${ }^{92}$ In their successive and competing attempts to adapt governance to take account of the supposed peculiarities of the tribal society, colonial officials created numerous opportunities for the Mahsuds to appropriate and exploit the largesse of an expanding colonial state and its aspiring officials.

\section{VI}

Despite the innovations and investments of over four decades, the long-awaited pacification of the Mahsuds remained a chimera. Dismayed frontier officials were increasingly confronted with the realization that their efforts to 'civilize' the Mahsuds had done little to subordinate the tribe. Further punitive expeditions were launched in 1917, 1919, and 1921, and another major campaign took place in 1936-37. ${ }^{93}$ Despite the increasing application of airpower, and a variety of other innovations, colonial control over Waziristan was so tenuous as to be negligible. Upon reading Evelyn Howell's 1931 history of British relations with the Mahsuds, one colonial official was said to have lamented, 'what a record of futility it all is!'94

Though it is perhaps tempting to read Waziristan's postcolonial history in relation to the putative 'failure' of colonial governance, such an approach would reproduce the Whiggish assumption that 'progress' towards modern forms of nation and statehood is natural. To understand colonial relations with the Mahsuds, both the process of colonial state-building and the categories through which it was made intelligible (nation, state, tribe) require historicization. We should not, therefore, depict colonial policies in terms of their 'failure' or their 'success'. Rather, we should examine how novel forms of colonial intervention were assembled and resisted along the frontier. Such an approach reveals the dynamic and contested nature of colonial state-building and helps us to better understand how colonial governance rested on, and helped to shape, representations of 
At the edge of empire

frontier.

While calculated to mitigate day-to-day administrative problems (and to burnish careers and reputations), the projects this paper has examined - both military and civilian - also reflected and sustained the interventionist and expansionist logics on which colonial rule depended. The collapse of colonization schemes and other 'conciliatory' methods justified the use of military expeditions, and the apparent inefficiency of these expeditions in turn compelled colonial officials - keen, like their colleagues in the military, to advance their own careers - to explore alternative modes of pacification. The 'record of futility' inscribed in the imperial archive thus partly reflects the iterative workings of the colonial state, and the bureaucracy on which it depended. Though the minutes, despatches and reports produced by colonial officials inevitably stress the novelty and promise of their own labours, while frequently denigrating those who preceded them - as Merk did to Bruce, and Curzon to earlier Viceroys - historians need to look beyond these claims to discern the modes and forms through which colonial authority was constructed and contested. The co-constitution of 'tribe' and 'state' may be traced in the constrained evolution of colonial practices as much as in the proverbially redoubtable 'nature' of tribal social structures. While there is a considerable literature on the latter ${ }^{95}$, much less attention has been paid to the ways in which colonial projects may be read to reveal the contingencies and limits of imperial power.

From this perspective, violence was not only a key vector for the expansion of colonial influence in South Waziristan but also a means by which that expansion could be resisted, deflected and appropriated. Contrary to the romanticized vision of frontier warfare bequeathed by Kipling and Churchill, however, this violence only rarely involved direct conflict between colonial troops and tribal forces. Even when the Indian Army took the field to 'punish' the Mahsuds, that punishment was invariably constituted through material depredation rather than military 
At the edge of empire

engagement. ${ }^{96}$ The strategic calculus which shaped frontier warfare overlapped and extended the forms of pacification attempted through settlement schemes, blockades and militia service. In seeking to forcibly remake the relationship between tribal populations and the colonial government - to dissuade raiding or to 'humanise' the tribes - such projects rested on similar forms of knowledge and mobilized equivalent dispositions of force, reflecting the epistemological and material scaffolds of colonial state-building.

While the exceptional nature of colonial law on the frontier has now been recognized, ${ }^{97}$ the epistemic violence of colonial jurisprudence depended on a wider apparatus of colonial violence. The legal and juridical frames through which colonialism attempted to assert itself were equally dependent on those military and civilian projects that gave British rule its material form along the frontier. The territorialization of colonial governmentality was marched along the frontier by sepoys and militia men, inscribed by the pens of surveyors, and dug into the land via canals, fortifications and settlements. While these instantiations were often fleeting and frequently flawed, we should not lose sight of the many ways in which colonial governmentality was realized by these schemes, as much as by judges and administrators. ${ }^{98}$

Neither must we lose sight of the limits of this form of rule. As we have seen, the territorialization of colonial rule was an unstable, fractured and ultimately incomplete project. ${ }^{99}$ The complexities of colonial governance along the frontier reflected the complexity of the local societies it attempted to subsume, as well as the ability of those groups to respond to and resist colonial penetration. As Marsden and Hopkins have argued, pervasive and simplistic accounts of this region have obscured our ability to make sense both of the populations who lived there and of their interactions with colonialism. ${ }^{100}$ While it is beyond the scope of this article to reconstruct Mahsud resistance in greater detail (though such work is overdue), we have seen how interactions 
At the edge of empire

between the Mahsuds and the colonial state were complex, multi-faceted and dynamic. As the examples here make clear, the frontier encounter was always reciprocal and negotiated. Allowances, recruitment, hostages, requisitioning and colonization schemes all offered opportunities for the Mahsuds to mediate, deflect, appropriate and bend colonial interventions to their own interests. Flexibility and engagement, not fanaticism or flight, marked indigenous resistance to colonial incursions in South Waziristan. The depiction of the Mahsuds - and Pashtuns more generally - as implacable opponents of colonialism is unhelpful, and sustaining this vision requires us to overlook the considerable evidence of cooperation and collaboration. The Mahsud propensity to repeatedly thwart colonial ambitions lies not in some unchanging form of 'tribal culture', but in the dynamics which shape that most common human endeavour: the political struggle to produce and resist power.

As policy-makers and historians raid the colonial archive to provide perspective on contemporary conflicts, it seems both timely and necessary to reassert the possibility, and the value, of more critical histories of empire. If Britain's imperial history has lessons to offer, they concern the hubris of essentialism and the dangers of instrumentalism. Recognising what was common to the antagonists of the nineteenth century may help to complicate the binaries that so limit understandings of ongoing conflicts in South Asia and beyond. Without a better understanding of how imperial power operated - and how it was resisted - we will learn nothing from history, except that nothing can be learned from history.

School of History, Queen Mary, University of London, Mile End Road, London E1 4NS m.condos@qmul.ac.uk Department of History, Politics and Social Sciences, University of Greenwich, Old Royal Naval College, 30 Park Row, LondonSE109LS G.T.Rand@greenwich.ac.uk 
* We would like to acknowledge and thank Martin Bayly, Kim A. Wagner, Dev Moodley, Sujit Sivasundaram, and the three anonymous reviewers for their constructive comments and assistance in preparing this article.

${ }^{1}$ See, generally, Richard Temple and R.H. Davies, Report showing the relations of the British government with the tribes of the North-West Frontier of the Punjab from annexation in 1849 to the close of 1855; and continuation of the same to August 1864 (Lahore, 1865), British Library (BL), India Office Records (IOR), V/27/273/1/1; C.C. Davies, The problem of the North-West Frontier 1890-1908, with a survey of policy since 1849 (Cambridge, 1932); Akbar S. Ahmed, Pukhtun economy and society: traditional structure and economic development in tribal society (London, 1980); and Hugh Beattie, Imperial frontier: tribe and state in Waziristan (Richmond, 2002).

${ }^{2}$ Andrew M. Roe, Waging war in Waziristan: the British struggle in the land of bin Laden, 1849-1947 (Lawrence, KS, 2010); M.M. Matthews, An ever present danger: a concise history of British military operations on the NorthWest Frontier, 1849-1947 (Fort Leavenworth, KS, 2010); Matthew W. Williams, The British colonial experience in Waziristan and its applicability to current operations (Fort Leavenworth, KS, 2005), United States Department of Defence: Defence Technical Information Center <http://www.dtic.mil/dtic/tr/fulltext/u2/a436296.pdf>; John Ferris, 'counter-insurgency and empire: the British experience with Afghanistan and the North-West Frontier, 1838-1947', in Scott Gates and Kaushik Roy (eds.), War and state-building in Afghanistan: historical and modern perspectives (London, 2015), pp. 79-112.

${ }^{3}$ Though we follow the colonial sources in referring to 'tribe', we recognize that contemporary understandings of 'tribe' owe much to colonial ethnographies, which were invariably shaped by the security concerns of the expanding colonial state. See Richard Tapper, 'Introduction', in ibid.(ed.), The conflict of tribe and state in Iran and Afghanistan (London, 1983), pp. 5-6, 42; James C. Scott, The art of not being governed: an anarchist history of upland Southeast Asia (New Haven, CT, 2009), pp. 31-32; and Hugh Beattie, 'Custom and conflict in Waziristan: some British views', in Benjamin D. Hopkins and Magnus Marsden (eds.), Beyond Swat: history, society and economy along the Afghanistan-Pakistan frontier (London, 2012), p. 211.

${ }^{4}$ R. Stewart, 'The irresistible illusion', London Review of Books, 31 (2009), pp. 3-6.

${ }^{5}$ Charles Allen, Soldier sahibs: the men who made the North-West Frontier (London, 2000); Christian Tripodi, Edge of empire: the British political officer and tribal administration on the North-West Frontier 1877-1947 (Farnham, 2011), which describes the frontier's inhabitants as 'unruly', 'intractable', 'misbehaving', and in need of 'taming'. On the persistence of colonial stereotypes in contemporary political discourse, see Mark Condos, 
"Fanaticism" and the politics of resistance along the North-West Frontier of British India', Comparative Studies in Society and History, 58 (2016), pp. 717-745. For a useful summary of the problems of much of the extant literature, see Benjamin D. Hopkins and Magnus Marsden, Fragments of the Afghan frontier (Oxford, 2011).

${ }^{6}$ Tripodi, Edge of empire, p. 16.

${ }^{7}$ Sameetah Agha, 'Inventing a frontier: imperial motives and sub-imperialism on British India's Northwest Frontier, 1889-98', in Sameetah Agha and Elizabeth Kolsky (eds.), Fringes of empire: peoples, places, and spaces in colonial India (Oxford, 2009), pp. 94-114; and Akbar S. Ahmed, 'Tribes and states in Waziristan' in Tapper, The conflict of tribe and state, pp. 192-211. For a critical appraisal of the underpinning 'great game narrative', see Martin J. Bayly, Taming the imperial imagination: colonial knowledge, international relations, and the Anglo-Afghan encounter, 1808-1878 (Cambridge, 2016), esp. pp. 10-15.

${ }^{8}$ As Christine Noelle has noted, Pashtun 'identities and political strategies have always been shaped by their interaction with greater powers': Christine Noelle, State and tribe in nineteenth century Afghanistan: the reign of Amir Dost Muhammed Khan (1826-1863) (Richmond, 1999), p. 123.

${ }^{9}$ Scott, The art of not being governed, p. xi.

${ }^{10}$ See, generally, Malcolm Yapp, 'Tribes and states in the Khyber, 1838-42', in Tapper, The conflict of tribe and state, pp. 151-187; Scott, The art of not being governed; Radhika Singha, A despotism of law: crime and justice in early colonial India (New Delhi, 1998); Andrew Major, 'State and criminal tribes in colonial Punjab: surveillance, control and reclamation of the "dangerous classes,"” Modern Asian Studies, 33 (1999), pp. 657-688.

${ }^{11}$ Radhika Singha, A despotism of law, pp. 169-70.

${ }^{12}$ Ranajit Guha, A rule of property for Bengal: an essay on the idea of permanent settlement (Paris, 1963).

${ }^{13}$ Robert Nichols, Settling the frontier: land, law, and society in the Peshawar Valley, 1500-1900 (Oxford, 2001$)$, p.

215; Robert Johnson, The Afghan way of war: culture and pragmatism: a critical history (London, 2011), p. 35.

14 'District memorandum, Derah Ismael Khan, 1852', in Temple and Davies, Report, p. 171.

15 Nichols, Settling the frontier, p. 216.

${ }^{16}$ Davies, The problem of the North-West Frontier, p. 25; Temple and Davies, Report.

${ }^{17}$ Ibid., p. 123, p. 116.

${ }^{18}$ Temple and Davies, Report, p. 97.

${ }^{19}$ G.J. Younghusband, Indian frontier warfare (London, 1898), p. 7. 
${ }^{20}$ See C.E. Callwell, Small wars: their principles and practice (1896; London, 1906); also Frontier warfare 1901, (Simla, 1901); and Winston S. Churchill, The story of the Malakand Field Force: an episode of frontier war (London, 1898); G.F. MacMunn, The romance of the Indian frontiers (London, 1931).

${ }^{21}$ For a more detailed discussion of colonial frontier warfare, see G. Rand, "“From the Black Mountain to Waziristan": culture and combat on the North-West Frontier' in K. Roy and G. Rand (eds.), Culture, conflict and the military in colonial South Asia (London, 2017).

${ }^{22}$ Benjamin D. Hopkins, 'The Frontier Crimes Regulation and frontier governmentality', The Journal of Asian Studies, 74 (2015), pp. 1-22; Elizabeth Kolsky, 'The colonial rule of law and the legal regime of exception: frontier “fanaticism" and state violence in British India', American Historical Review, 120 (2015), pp. 1218-1246.

${ }^{23}$ David Scott, Refashioning futures: criticism after postcoloniality (Princeton, NJ, 1999).

${ }^{24}$ W.H. Paget and A.H. Mason, A record of expeditions against the tribes of the North-West Frontier since the annexation of the Punjab (London, 1884), p. 506.

${ }^{25}$ Beattie, Tribe and state, pp. 29-34

${ }^{26}$ A.H. Mason, Report on the Mahsud Waziri tribe (Simla, 1893), BL, IOR, L/PS/20/B104, p. 32.

${ }^{27}$ Paget and Mason, A record of the expeditions, p. 508

${ }^{28}$ See H.C. Wylly, From the Black Mountain to Waziristan: being an account of the border countries and the more turbulent of the tribes controlled by the North-West Frontier Province, and of our military relations with them in the past (London, 1912), p. 447.

${ }^{29}$ Mason, Report on the Mahsud Waziri tribe, p. 36.

${ }^{30}$ Chamberlain to the Punjab Government (PG), 7 July 1860, National Archives of India (NAI), Foreign/Political A/Nov. 1862, nos. 99-101, no. 100, p. 16.

${ }^{31}$ Ibid, p. 20.

32 Ibid.

33 Taylor to the PG, 6 Dec. 1861, NAI Foreign/Political A/Jan. 1862/nos. 108-110, para. 7.

${ }^{34}$ Graham to the Commissioner and Superintendent of Derajat, 8 Aug., 1865, NAI, Foreign/Political A/Jan. 1866/nos. 87-90, no. 88 , para. 12 .

${ }^{35}$ Extract from the proceedings of the GOI, 18 Dec., 1865, NAI, Foreign/Political A/Jan. 1866/nos. 87-90, no. 89, p. 5. 
${ }^{36}$ Ibid; PG to the GOI, 4 Dec. 1865, ibid., no. 87, p. 1; also NAI, Foreign/Frontier A/Sept. 1896/nos. 84-91, p. 1.

${ }^{37}$ Political letter by His Majesty's Secretary of State for India, 30 Apr. 1866, BL, IOR, L/PS/6/456, p. 1195.

${ }^{38}$ PG to the GOI,10 Nov. 1873, NAI, Foreign/Political A/nos. 356-370, para. 6, p. 2; Hugh Beattie, 'Negotiations with the tribes of Waziristan 1849-1914 - the British experience', The Journal of Imperial and Commonwealth History, 39 (Nov. 2011), p. 579.

${ }^{39}$ Memorandum on border policy, Dec. 1866, NAI/Foreign/Secret/Sept. 1872/nos. 60-83, no. 61, p. 10.

${ }^{40}$ Translation of a petition from Gholam Nabbi Khan, NAI, Foreign/Political A/May 1877/nos. 180-188, no. 181, p. 1.

${ }^{41}$ Macaulay to Munro, 23 Feb. 1877, ibid., no. 184, para. 1, p. 1.

${ }^{42}$ Macaulay to Munro, 25 Feb. 1877 , ibid., no. 187 , para. 4, p. 3.

${ }^{43}$ PG to the GOI, 22 Mar. 1877, ibid., no. 180, para. 6, p. 1.

${ }^{44}$ PG to the GOI, 2 June 1882, NAI, Foreign/Political A/July 1882/nos. 261-268, no. 261, para. 3, p. 1.

${ }^{45}$ PG to the GOI, 3 Jan. 1881, BL, IOR, L/MIL/17/13/107, p. 4.

${ }^{46}$ Hugh Beattie, 'Hostages on the Indo-Afghan border in the later nineteenth century', The Journal of Imperial and Commonwealth History, 43 (2015), pp. 561-62; also ibid., Imperial frontier, p. 130.

${ }^{47}$ R.I. Bruce, The forward policy and its results; or thirty-five years' work amongst the tribes on our North-Western Frontier of India (London, 1900), p. 85.

${ }^{48}$ Ibid., Memorandum on our past and present relations with the Waziri tribe (especially the Mahsud section) and the Bhittanni tribe on the Dera Ismail-Khan border, 1888, BL, IOR, Mss Eur F163/8, p. 26.

${ }^{49}$ Waziristan and the lessons of the 60 years (Simla, 1921), BL, IOR, L/MIL/17/13/123, pp. 4-34.

${ }^{50}$ See, for example, 'The Waziri expedition', Pioneer, 10 June 1881, qtd. in BL, IOR, L/MIL/17/13/107, pp. 89-90.

${ }^{51}$ Diary entry, 27 Apr. 1881, BL, IOR, L/MIL/17/13/107, p. 59.

${ }^{52}$ Kennedy to the PG, 5 Feb. 1881, ibid., p. 10.

${ }^{53}$ PG to Kennedy, 13 Apr. 1881, ibid., p. 47.

${ }^{54}$ Diary entry, 18 May 1881, ibid., p. 85.

${ }^{55}$ For a broader, perhaps overstated, analysis of the imperial military and colonial knowledge, see James Hevia, The imperial security state: British colonial knowledge and empire-building in South Asia (Cambridge, 2012), pp. 73106. 
${ }^{56}$ Ahmed, 'Tribes and states', p. 198.

57 The British intended that these hostages be used as chalweshtis - a 'traditional' tribal militia that could be used to police the Mahsuds themselves. Indicatively, the tribesmen regarded these as prized appointments, not as forms of punishment: Beattie, 'Hostages on the Indo-Afghan border', p. 563.

${ }^{58}$ NAI, Foreign/Political A/July 1882/nos. 8-40, 99-101; also Wylly, From the Black Mountain, p. 458.

59 'Intelligence received from the Mahsud hills', NAI, Foreign/Political A/Nov. 1881, nos. 161-212, no. 173, para. 2.

${ }^{60}$ Richard Temple, Report showing the relations of the British government with the tribes, independent and dependent, on the North-West Frontier of the Punjab, from annexation in 1849 to the close of 1855 (Calcutta, 1856), BL, IOR, V/23/3.

61 'Were this year's crops to be destroyed', the Pioneer claimed, 'starvation must ensue'. 'The Waziri expedition', Pioneer, 10 May 1881, qtd. in BL, IOR, L/MIL/17/13/107, p. 31.

${ }^{62}$ Ommanney to the PG, 12 Apr. 1882, NAI, Foreign/Political A/June 1882, nos. 261-268, np. 262, para. 4, p. 2.

${ }^{63}$ Gazetteer of the Bannu district 1883-84 (Calcutta, 1884), BL, IOR, V/27/67/6, p. 99.

${ }^{64}$ Bruce, Memorandum, BL, IOR, Mss Eur F163/8, pp. 46-47.

${ }^{65}$ Ogilvie to Ommanney, 21 Jan. 1887, NAI, Foreign/Frontier A/June 1887/nos. 23-26, no. 25, para. 5, pp. 3-4.

${ }^{66}$ King to Bruce, 11 Mar. 1892, NAI, Foreign/Frontier A/June 1892/nos. 69-74, para. 4, pp. $2-3$.

${ }^{67}$ A.H. Mason and G.K. Cotherill, Operations against the Mahsud Waziris by a force under the command of Lieutenant-General Sir W.S.A. Lockhart, in 1894-95 (Simla, 1897), BL, IOR, L/MIL/17/13/108, pp. 17, 19.

${ }^{68}$ Papers regarding British relations with neighbouring tribes on N.W. Frontier of India and military operations, 1897-98; Command papers: accounts and papers; 1898 (Cd. 8713-8714), LXIII.3, pp. 30-31. 1898; and Evelyn Howell, Mizh: a monograph on government's relations with the Mahsud tribe (1931; Karachi, 1979), p. 9.

69 ‘Mason and Cotherill, Operations against the Mahsud Waziris, pp. 43-46.

70 'Memorandum by Mr. A.J. Grant, Political Officer', in ibid., appendix XIX.

${ }^{71}$ Ibid., p. 62.

${ }^{72}$ Howell, Mizh, p. 9.

${ }^{73}$ Enclosure no. 281 from Bruce, 15 Apr. 1896, NAI, Foreign/Frontier A/Sept. 1896/nos. 84-91.

${ }^{74}$ GOI to the PG, 3 Sept. 1896, ibid.

${ }^{75}$ Enclosure no. 281 from Bruce, 15 Apr. 1896, ibid. 
${ }^{76}$ D.A. Washbrook, 'Law, state and agrarian society in colonial India', Modern Asian Studies, 15 (1981), pp. 649721.

${ }^{77}$ Lord Curzon of Kedleston, Frontiers (Oxford, 1907), p. 7.

${ }^{78}$ David Gilmour, Curzon: imperial statesman (London, 2003), pp. 196-198.

${ }^{79}$ Patrick Joyce, The state of freedom: a social history of the British state since 1800 (Cambridge, 2013), pp. 150152.

${ }^{80}$ GOI to Hamilton, 30 Jan. 1902, Papers relating to Mahsud-Waziri operations (East India: North-West Frontier). Command papers: accounts and papers; 1902 (Cd. 1177), LXXI, p. 155.

${ }^{81}$ Wylly, From the Black Mountain, p. 470.

${ }^{82}$ Merk to Deane, 6 Mar., 1902, BL, IOR, L/MIL/17/13/109, p. 281; also Wylly, From the Black Mountain, p. 472.

${ }^{83}$ As with punitive expeditions, the aim of 'enhanced blockade' was to 'demolish all defences, capture prisoners and cattle, and destroy grain and fodder': Wylly, From the Black Mountain, p. 471.

${ }^{84}$ Merk to the PG, 1 July 1901, NAI, Foreign/Frontier A/July 1901/ nos. 10-39, no. 39, pp. 6-7.

${ }^{85}$ Deane to the GOI, 27 Mar. 1902, BL, IOR, L/MIL/17/13/109, p. 285.

${ }^{86}$ Anderson to the PG, 24 Jan. 1900, Papers relating to Mahsud-Waziri operations, p. 56.

${ }^{87}$ Note by P. Pipon, 1 Feb. 1902, ibid., p. 273.

${ }^{88}$ Testimony of Nazam Khan, May 1902. NAI, Foreign/Frontier A/July 1901/nos. 10-39, no. 36, p. 17.

${ }^{89}$ See NAI, Foreign/Frontier B/Feb. 1901/nos. 193-204.

${ }^{90}$ Note by P. Pipon, 1 Feb. 1902, Papers relating to Mahsud-Waziri operations, p. 274; also H.L. Nevill, Campaigns on the North-West Frontier (London, 1912) p. 326.

${ }^{91}$ Hugh Beattie, 'Beattie, 'Hostages on the Indo-Afghan border', p. 563.

92 Beattie, 'Custom and conflict', pp. 214-6

${ }^{93}$ A. Warren, “'Bullocks treading down wasps?”: The British Indian army in Waziristan in the 1930s', South Asia: Journal of South Asian Studies, 20 (1997), pp. 35-56.

${ }^{94}$ Howell, Mizh, p. 95.

${ }^{95}$ See Ahmed, Pukhtun economy and society; ibid., 'Tribes and states in Waziristan'; Beattie, Imperial frontier. 
At the edge of empire

${ }^{96}$ The emphasis on those relatively infrequent moments of direct engagement, including in revisionist accounts, is thus somewhat misleading. See, for example, Antoinette Burton, The trouble with empire: challenges to modern British imperialism (Oxford, 2015), pp. 24-86.

${ }^{97}$ Mark Condos, 'Licence to kill: The Murderous Outrages Act and the rule of law in colonial India', Modern Asian Studies, 50 (Mar. 2016), pp 479-517; Hopkins, 'The Frontier Crimes Regulation'.

${ }^{98}$ For comparisons, see C. Mukerji, Impossible engineering: technology and territoriality on the Canal du Midi (Princeton, NJ, 2009); Simanti Dutta, Imperial mappings in savage spaces: Baluchistan and British India (New Delhi, 2002); Daniel Haines, Building the empire, building the nation: development, legitimacy, and hydro-politics in Sind, 1919-1969 (Oxford, 2013).

${ }^{99}$ As recently as the 1980s, the long-anticipated 'pacification' of Waziristan was being mooted by the frontier official-cum-scholar A.S. Ahmed: Ahmed, 'Tribes and states’, pp. 200-01.

${ }^{100}$ Hopkins and Marsden, Fragments of the Afghan frontier, pp. 215-9. 